\title{
Effect of propofol on lung metastasis of circulating tumor cells after colorectal cancer surgery
}

\author{
Shi Wu*, Shiting Jia, Houwen Long \\ Department of Anorectal Surgery, The First People's Hospital of Yongkang, Yongkang 321300, Zhejiang Province, China \\ *For correspondence: Email: ngicm8@163.com
}

Sent for review: 19 January 2021

Revised accepted: 26 April 2021

\begin{abstract}
Purpose: To investigate the effect of propofol on lung metastasis of circulating tumor cells (CTCs) after colorectal cancer (CRC) surgery, and the mechanism involved.

Methods: Specific-pathogen-free (SPF) male BALB/c mice $(n=30$; mean age $=7 \pm 1$ weeks; mean weight $=19 \pm 3 \mathrm{~g}$ ) were used for this study. To establish mouse model of CRC, $100 \mu \mathrm{L}$ of CRC (CT26) cells was injected into the caudal vein of each mouse. Three groups of 10 mice were used: control, 5 $\mu \mathrm{L} / \mathrm{mL}$ propofol, and $10 \mu \mathrm{L} / \mathrm{mL}$ propofol groups. Changes in pulmonary superficial nodules of mice lungs were determined. Colorectal cancer cell (CT26) proliferation and apoptosis were measured using Ki-67 immunohistochemical staining and in situ terminal deoxynucleotide transferase-mediated dUTP nick end labeling (TUNEL) assays, respectively.

Results: The number of pulmonary nodules and proportion of proliferating cells (Ki-67 expression level) were significantly higher in $5 \mu \mathrm{L} / \mathrm{mL}$ propofol-treated mice, relative to control, but markedly lower in 10 $\mu \mathrm{L} / \mathrm{mL}$ propofol group than in $5 \mu \mathrm{L} / \mathrm{mL}$ propofol group $(p<0.05)$. Although apoptotic index increased in 5 $\mu L / m L$ propofol group, cell apoptosis was comparable among the groups $(p>0.05)$.

Conclusion: These results suggest that propofol promotes pulmonary metastasis of CTCs after CRC surgery via stimulation of CTC proliferation in the lungs. Therefore, caution should be exercised in the use of propofol in colorectal cancer surgery.
\end{abstract}

Keywords: Apoptosis, Colorectal cancer, Circulating tumor cell, Lung metastasis, Propofol

\begin{abstract}
This is an Open Access article that uses a fund-ing model which does not charge readers or their institutions for access and distributed under the terms of the Creative Commons Attribution License (http://creativecommons.org/licenses/by/4.0) and the Budapest Open Access Initiative (http://www.budapestopenaccessinitiative.org/read), which permit unrestricted use, distribution, and reproduction in any medium, provided the original work is properly credited.
\end{abstract}

Tropical Journal of Pharmaceutical Research is indexed by Science Citation Index (SciSearch), Scopus, International Pharmaceutical Abstract, Chemical Abstracts, Embase, Index Copernicus, EBSCO, African Index Medicus, JournalSeek, Journal Citation Reports/Science Edition, Directory of Open Access Journals (DOAJ), African Journal Online, Bioline International, Open-J-Gate and Pharmacy Abstracts

\section{INTRODUCTION}

The number of tumor patients has increased significantly over time, with malignant tumor becoming one of the most important causes of death globally. Colorectal cancer (CRC) is a type of cancer prevalent among the Chinese. It is characterized by high incidence and mortality which have continued to rise on annual basis [1]. Colorectal cancer (CRC) patients often miss diagnosis and treatment because early symptoms of the disease are usually not obvious. Prognosis is also usually poor, since CRC patients are either in the middle or advanced stage of the disease at the time of diagnosis [2].

Metastasis seriously affects effectiveness of cancer treatment. At present, surgical resection is the main treatment strategy for CRC. However, studies have shown that even after complete 
resection of primary tumor, undetected micrometastases are capable of causing recurrence, thereby making postoperative metastasis and recurrence the most important factors that affect prognosis of CRC [3]. Colorectal cancer (CRC) cells directly or indirectly enter the systemic circulation through the lymphatic route, thereby colonizing distant tissues/organs, and eventually proliferating to form metastasis focus [4]. Circulating tumor cells (CTCs) are tumor cells that are passed into the blood from primary or metastasis focus [4]. They are responsible for distant metastasis.

Anesthesia, an indispensable part of perioperative period, has close relationship with patients' immune function and postoperative tumor recurrence and metastasis [5]. Propofol is a frequently used intravenous anesthetic with the advantages of quick induction time, minimal toxicity and low side effects. Moreover, propofol exerts immunomodulatory, antioxidant, neuroprotective, and anxiolytic effects. Studies have shown that propofol has little effect on immune function of patients undergoing CRC surgery, but it has regulatory effect on CRC formation [6]. This study investigated the effect of propofol on lung metastasis of CTCs after CRC surgery, as well as the mechanism involved.

\section{EXPERIMENTAL}

\section{Materials}

Colorectal cancer cell line (CT26) was bought from Shanghai Keyuandi Biotechnology Co. Ltd. Carbon dioxide incubator (HH.CP-T) was purchased from Beijing Hengtai Fengke Test Equipment Co. Ltd. Constant temperature water bath (HWT-6B) was product of Tianjin Hengao Technology Development Co. Ltd. Fullautomatic tissue dehydrator (TSJ-1C) was obtained from Shanghai Kehuai Instrument Co. Ltd. Paraffin slicer (RM2245) was bought from Beijing Shengke Xinde Technology Co. Ltd. Fetal bovine serum (FBS) was purchased from Shanghai Jianglin Biotechnology Co. Ltd. Trypsin was product of Shanghai Ruji Biotechnology Co. Ltd., while propofol was bought from Sichuan Guorui Pharmaceutical Co. Ltd.

\section{Cell culture}

Colorectal cancer cells (CT26) were cultured in DMEM supplemented with $10 \%$ FBS and $1 \%$ penicillin/streptomycin solution at $37^{\circ} \mathrm{C}$ for $24 \mathrm{~h}$ in a $5 \% \mathrm{CO}_{2}$ incubator until the cells attained 85 $\%$ confluency. The resultant adherent cells were trypsinized with $2 \mathrm{~mL}$ of $0.25 \%$ trypsin, and centrifuged at $1500 \mathrm{rpm}$ for $10 \mathrm{~min}$. The cell mass was then reduced to single cell suspension which was inoculated into a $25 \mathrm{~cm}^{2}$ culture dish at a density of $2 \times 10^{4}$ cells/well $(100 \mu \mathrm{L}$ per well $)$ and incubated. When the cells attained $60-70 \%$ confluency, they were treated with serum-free medium and varied concentrations of propofol for $24 \mathrm{~h}$. Normal cell culture without propofol served as control group. Cells in logarithmic growth phase were counted and seeded in 6-well plates at a concentration of $4 \times 10^{4}$ cells/well. Each group had 4 replicates.

\section{Mice}

Specific-pathogen-free (SPF) male BALB/c mice $(\mathrm{n}=30)$ aged 6 to 8 weeks, and weighing $16-$ $22 \mathrm{~g}$ (mean age $=7 \pm 1$ weeks; mean weight = $19 \pm 3 \mathrm{~g}$ ) were obtained from School of Medicine, Shantou University, Guangdong, China. They were exposed to equal durations of light and darkness at $25{ }^{\circ} \mathrm{C}$ and humidity of $45-55 \%$. The study protocol was approved by the Institutional Animal Ethics Committee (approval no. 2019-03015), and the study procedures used conformed with the directives of AAALAC [7].

\section{Study design}

A mouse model of CRC was established by injecting $100 \mu \mathrm{L}$ of CT26 cells into the caudal vein of each mouse. Three groups of 10 mice were used: control, $5 \mu \mathrm{L} / \mathrm{mL}$ propofol, and 10 $\mu \mathrm{L} / \mathrm{mL}$ propofol groups. Mice in propofol groups were intraperitoneally injected with 5 and 10 $\mu \mathrm{L} / \mathrm{mL}$ of propofol. The mice were then fed adaptively for 1 week and euthanized. Fresh lung from each mouse was fixed in $10 \%$ formaldehyde solution and pulmonary superficial nodules of mice in each group were counted. Pulmonary superficial nodules $>10$, but not filled with lungs were counted as 15 , while pulmonary superficial nodules $>10$ and filled with lungs were counted as 20 .

\section{Immunohistochemical staining}

Cell proliferation was determined using $\mathrm{Ki}-67$ immunohistochemical staining method. The cells were plated on gelatin-coated coverslips, followed by fixation in $4 \%$ paraformaldehyde in an oven at $60{ }^{\circ} \mathrm{C}$ for $20 \mathrm{~min}$, and washing thrice in phosphate-buffered saline for $5 \mathrm{~min}$. The slides were deparaffinized with xylene, dehydrated with ethanol, and exposed to briefly 3 $\% \mathrm{H}_{2} \mathrm{O}_{2}$ to minimize background stain. Following treatment with citric acid buffer for $15 \mathrm{~min}$ in a microwave oven, the slides were exposed to Ultra V Block stain at laboratory temperature for $10 \mathrm{~min}$. Thereafter, rabbit anti-Ki-67 monoclonal antibody was added, and the slides were 
incubated for $2 \mathrm{~h}$. Ultra-vision LP System was used for measurement of binding of antibody. The slides were stained with $D A B$, followed by counterstaining using hematoxylin. The proportion of positive cells was calculated. Results $<6 \%$ were considered low, while counts of $6-10 \%$ and $>10 \%$ were considered intermediate and high, respectively. The Ki-67 expression level in each group of cells was determined using western blotting.

\section{Apoptosis assay}

Cell apoptosis was measured using TUNEL assay. The cells were plated on gelatin-coated coverslips, fixed with $4 \%$ paraformaldehyde in an oven at $60{ }^{\circ} \mathrm{C}$ for $20 \mathrm{~min}$, and washed thrice with PBS for $5 \mathrm{~min}$. After blocking with $1 \%$ bovine serum albumin for $60 \mathrm{~min}$ at laboratory temperature, $1^{\circ}$ antibody was added and further incubated for $12 \mathrm{~h}$ at $4{ }^{\circ} \mathrm{C}$. After washing thrice with PBS, FITC-labeled secondary antibody was added and incubated for $1 \mathrm{~h}$ at room temperature. The slides were thereafter stained with 4', 6-diamidino-2-phenylindole (DAPI) for 15 min and washed for $5 \mathrm{~min}$. The slides were observed under a fluorescence microscope in the dark, and photographed after the addition of antifluorescent quenching agent. The apoptotic index of each group of cells was calculated.

\section{Statistical analysis}

Results are presented as mean \pm SEM, and were statistically analyzed with SPSS (20.0). Group comparison was done using Duncan's multiple range test and Student's $t$-test. Values of $p<$ 0.05 were taken as indicative of statistically significant differences.

\section{RESULTS}

\section{Changes in the number of pulmonary nodules of mice}

The number of pulmonary nodules was significantly higher in $5 \mu \mathrm{L} / \mathrm{mL}$ propofol-treated mice, relative to control, but was markedly lower in $10 \mu \mathrm{L} / \mathrm{mL}$ propofol group than in $5 \mu \mathrm{L} / \mathrm{mL}$ propofol group ( $p<0.05$; Table 1$)$.

\section{Effect of propofol on CT26 cell proliferation}

As presented in Table 2, the proportion of proliferating cells (Ki-67 expression level) was significantly higher in $5 \mu \mathrm{L} / \mathrm{mL}$ propofol-treated mice, relative to control, but was markedly lower in $10 \mu \mathrm{L} / \mathrm{mL}$ propofol group than in $5 \mu \mathrm{L} / \mathrm{mL}$ propofol group $(p<0.05)$.
Table 1: Changes in the number of pulmonary nodules of mice (mean $\pm S D, n=10$ )

\begin{tabular}{lc}
\hline Group & No. of pulmonary nodules \\
\hline Control & $4.26 \pm 0.93$ \\
Propofol $(5 \mu \mathrm{L} / \mathrm{mL})$ & $16.52 \pm 5.87^{\mathrm{a}}$ \\
Propofol $(10 \mu \mathrm{L} / \mathrm{mL})$ & $12.23 \pm 6.22^{\mathrm{a}, \mathrm{b}}$ \\
$f$ & 15.69 \\
$P$-value & $<0.001$ \\
\hline${ }^{a} P<0.05$, vs control; ${ }^{\mathrm{b}} p<0.05$, vs $5 \mu \mathrm{L} / \mathrm{mL}$ propofol \\
group
\end{tabular}

Table 2: CT26 cell proliferation (mean $\pm S D, n=4$ )

\begin{tabular}{lc}
\hline Group & $\begin{array}{c}\text { Proportion of } \\
\text { proliferating cells (\%) }\end{array}$ \\
\hline Control & $20.67 \pm 10.36$ \\
Propofol $(5 \mu \mathrm{L} / \mathrm{mL})$ & $51.52 \pm 5.74^{\mathrm{a}}$ \\
Propofol $(10 \mu \mathrm{L} / \mathrm{mL})$ & $39.53 \pm 13.47^{\mathrm{a}, \mathrm{b}}$ \\
$F$ & 9.02 \\
$P$-value & 0.007 \\
\hline $\mathrm{a} P<0.05$, vs control; ${ }^{\mathrm{b}} p<0.05$, compared with 5 \\
$\mu \mathrm{L} / \mathrm{mL}$ propofol group
\end{tabular}

\section{Effect of propofol on CT26 cell apoptosis}

Although apoptotic index was increased in 5 $\mu \mathrm{L} / \mathrm{mL}$ propofol group, percentage cell apoptosis was comparable among the groups $(p>0.05$; Table 3).

Table 3: Comparison of cell apoptosis among the groups (mean $\pm S D, n=4$ )

\begin{tabular}{lc}
\hline Group & Apoptotic index \\
\hline Control & $5.02 \pm 3.46$ \\
Propofol $(5 \mu \mathrm{L} / \mathrm{mL})$ & $7.23 \pm 3.58$ \\
Propofol $(10 \mu \mathrm{L} / \mathrm{mL}$ & $5.56 \pm 2.17$ \\
$F$ & 0.54 \\
$P$-value & 0.601 \\
\hline
\end{tabular}

\section{DISCUSSION}

Colorectal cancer (CRC) is a tumor with high incidence. In-depth understanding of the biological behavior of CRC has led to the development of individualized comprehensive treatment comprising surgery, chemoradiotherapy, endocrine therapy and molecular targeted therapy. However, postoperative metastasis and recurrence have limited the effectiveness of such treatment plans [8]. Statistics show that $15 \%$ of CRC patients eventually develop lung metastasis. Metastasis involves the breaking away of tumor cells from the primary tumor into the systemic circulation. Most of the tumor cells get recognized and phagocytized by the body's immune system or apoptosis, while the few remaining tumor cells spread through the blood circulation in a dormant state known as CTCs [9]. 
The CTCs represent an intermediate stage of metastasis. They exist individually in the blood and cluster to form circulating tumor microemboli (CTM). Moreover, CTCs and CTM have become invaluable resources for research on various aspects of tumors. Most tumor cells that enter blood vessels get phagocytized by the body's autoimmune system; others undergo selfapoptosis after leaving the primary site, while the remaining tumor cells remain in a relatively static state, thereby playing a role in blood circulation, as well as becoming an important factor in tumor recurrence and metastasis [10]. Studies have shown that in an appropriate environment, CTCs become planted and transformed into tumor stem cells which may form the basis for local recurrence and distant metastasis [11]. Circulating tumor cells (CTCs) have prognostic significance in patients with early and metastatic cancers.

Anesthesiology is a perioperative discipline. The effect of anesthesia on immune function of patients may be an important factor that affects prognosis of tumor patients. Propofol is a commonly used phenolic intravenous anesthetic with rapid effect and short duration of action. It is widely used in the induction and maintenance of general anesthesia and auxiliary sedation of patients with regional block. Propofol has been reported to enhance the antioxidant capacity of cells via inhibition of cell apoptosis [12]. Studies have shown that propofol dose-dependently inhibited the invasion and migration of MCF7 cells [13]. This study investigated the effect of propofol on lung metastasis of CTCs after CRC surgery and the mechanism involved.

As a rapid mechanism of tissue growth, cell proliferation leads to an exponential increase in cell number. The compound $\mathrm{Ki}-67$ is an intracellular protein that binds DNA in the nucleolar region. The protein has a short half-life and is not affected by other growth factors [14]. It has been reported that $\mathrm{Ki}-67$ antibody has significant influence on a variety of tumors, and it is of great significance in the quantitative analysis of tumor growth fraction, tumor grading, degree of hyperplasia and prognosis [15]. The results of previous studies showed that the expression of Ki-67 was significantly upregulated in CTCs, but it was significantly downregulated at G0 phase of cell division cycle [16]. There is a link between $\mathrm{Ki}-67$ level and tumor cell proliferative potential. Indeed, this link is used routinely used as an index of proliferation in pathological studies. It is one of the most reliable indices for determination of proliferative capacity of primary tumor cells. The results of this study indicate that propofol may promote the proliferation of CTCs in the lungs and markedly increase the number of pulmonary metastatic nodules.

Apoptosis is a process of programmed cell death. At present, it is believed that induction of apoptosis is one way of treating cancer [17]. In this study, propofol had no significant effect on the apoptosis of colorectal CTCs.

\section{CONCLUSION}

The results obtained in this study indicate that propofol promotes pulmonary metastasis of CTCs after CRC surgery via stimulation of CTC proliferation in the lungs. Therefore, caution should be exercised in the use of propofol in colorectal cancer surgery.

\section{DECLARATIONS}

\section{Conflict of interest}

No conflict of interest is associated with this work.

\section{Contribution of authors}

We declare that this work was performed by the authors named in this article and all liabilities pertaining to claims relating to the content of this article will be borne by the authors. Shi Wu designed the study, supervised the data collection, and analyzed the data. Shiting Jia interpreted the data and prepared the manuscript for publication. Houwen Long supervised the data collection, analyzed the data and reviewed the draft of the manuscript.

\section{Open Access}

This is an Open Access article that uses a funding model which does not charge readers or their institutions for access and distributed under the terms of the Creative Commons Attribution License (http://creativecommons.org/licenses/by/ 4.0) and the Budapest Open Access Initiative (http://www.budapestopenaccessinitiative.org/rea d), which permit unrestricted use, distribution, and reproduction in any medium, provided the original work is properly credited.

\section{REFERENCES}

1. Sansone C, Nuzzo G, Galasso C, Casotti R, Fontana A, Romano $G$, lanora $A$. The Marine Dinoflagellate Alexandrium andersoni Induces Cell Death in Lung and 
Colorectal Tumor Cell Lines. Mar Biotechnol (NY) 2018; 20(3): 343-352.

2. Wang F, Song ZY, Qu XJ, Li F, Zhang L, Li WB, Cui SX. M10, a novel derivative of Myricetin, prevents ulcerative colitis and colorectal tumor through attenuating robust endoplasmic reticulum stress. Carcinogenesis 2018; 39(7): 889-899.

3. Gu K, Xu Y, Li H, Guo Z, Zhu S, Zhu S, Shi P, James TD, Tian H, Zhu WH. Real-Time Tracking and In Vivo Visualization of $\beta$-Galactosidase Activity in Colorectal Tumor with a Ratiometric Near-Infrared Fluorescent Probe. J Am Chem Soc 2016; 138(16): 5334-40.

4. Ribeiro-Samy S, Oliveira MI, Pereira-Veiga T, MuineloRomay L, Carvalho S, Gaspar J, Freitas PP, LopezLopez R, Costa C, Dieguez L. Fast and efficient microfluidic cell filter for isolation of circulating tumor cells from unprocessed whole blood of colorectal cancer patients. Sci Rep 2019; 9(1): 8032.

5. Yang $C$, Zhuang $W, H u Y, Z h u$ L. Clinical significance of peripheral circulating tumor cell counts in colorectal polyps and non-metastatic colorectal cancer. World $J$ Surg Oncol 2018; 16(1): 13.

6. Li Y, Dong W, Yang H, Xiao G. Propofol suppresses proliferation and metastasis of colorectal cancer cells by regulating miR-124-3p.1/AKT3. Biotechnol Lett 2020; 42(3): 493-504.

7. World Health Organization. Principles of laboratory animal care. WHO Chron 1985; 39: 51-56.

8. Han Z, Zhang A, Wang X, Sun Z, Wang MD, Xie T. In vivo use of hyperspectral imaging to develop a noncontact endoscopic diagnosis support system for malignant colorectal tumors. J Biomed Opt 2016; 21(1): 16001.

9. Schölch S, Garcia SA, Iwata N, Niemietz T, Betzler AM, Nanduri LK, Bork U, Kahlert C, Thepkaysone ML, Swiersy $A$, et al. Circulating tumor cells exhibit stem cell characteristics in an orthotopic mouse model of colorectal cancer. Oncotarget 2016; 7(19): 27232-42.
10. Li C, Pan R, Li P, Guan Q, Ao J, Wang K, Xu L, Liang X, Jin $X$, Zhang $C$, et al. Hydrogen Peroxide-Responsive Nanoprobe Assists Circulating Tumor Cell Identification and Colorectal Cancer Diagnosis. Anal Chem 2017; 89(11): 5966-5975.

11. Li Q. Dr. Masaki Hashimoto: clinical impact of circulating tumor cell in metastatic colorectal cancer patients who underwent pulmonary metastasectomy. J Thorac Dis 2017; 9(9): E845-E847.

12. Xu K, Tao W, Su Z. Propofol prevents IL-13-induced epithelial-mesenchymal transition in human colorectal cancer cells. Cell Biol Int 2018; 42(8): 985-993.

13. Bai JJ, Lin CS, Ye HJ, Guo PP, Wang W. Propofol suppresses migration and invasion of breast cancer MDA-MB-231 cells by down-regulating H19. Nan Fang Yi Ke Da Xue Xue Bao 2016; 36(9): 1255-1259.

14. Cidado J, Wong HY, Rosen DM, Cimino-Mathews A, Garay JP, Fessler AG, Rasheed ZA, Hicks J, Cochran $R L$, Croessmann $S$, et al. Ki-67 is required for maintenance of cancer stem cells but not cell proliferation. Oncotarget 2016; 7(5): 6281-6293.

15. Aziz S, Wik E, Knutsvik G, Klingen TA, Chen Y, Davidsen $B$, Aas H, Aas T, Akslen LA. Evaluation of Tumor Cell Proliferation by Ki-67 Expression and Mitotic Count in Lymph Node Metastases from Breast Cancer. PLoS One 2016; 11(3): e0150979.

16. Lowe AC, Pignon JC, Carvo I, Drage MG, Constantine NM, Jones N, Kroll Y, Frank DA, Signoretti S, Cibas ES. Young investigator challenge: Application of cytologic techniques to circulating tumor cell specimens: Detecting activation of the oncogenic transcription factor STAT3. Cancer Cytopathol 2015; 123(12): 696-706.

17. Jansson S, Bendahl PO, Larsson AM, Aaltonen KE, Ryden L. Prognostic impact of circulating tumor cell apoptosis and clusters in serial blood samples from patients with metastatic breast cancer in a prospective observational cohort. BMC Cancer 2016; 16:433. 